\title{
Financial development and the end-use of migrants' remittances
}

\author{
Michael Coon
}

Correspondence: coon@hood.edu Department of Economics and Business Administration, Hood College, 401 Rosemont Avenue, Frederick, MD 21701, USA

\begin{abstract}
This study examines how the level of financial development in a community affects households' decisions over how remittance income is spent. My findings suggest that in communities without banks remittances are more likely to be used for productive investments or to purchase assets. Increasing the size of the financial sector in communities with banks present increases the likelihood that remittances are used for productive investment and decreases the likelihood that remittances are used for general consumption. Finally, I find that the services offered by banks also affect the likelihood of using remittances for productive investment, purchasing assets, and general consumption.

JEL codes: F24; G21; D19.

Keywords: Remittances; Financial development; Mexico
\end{abstract}

\section{Introduction}

Total remittances to Mexico in 2008 were over US\$26 billion (World Bank 2010). Figure 1 shows that workers' remittances have grown steadily over the past 30 years and since 2005 have exceeded foreign direct investment as a source of capital inflows to Mexico. Given this trend, the potential impact of remittances on the economy is tremendous. Remittances differ from other forms of capital inflows, however, because they need not only be used for investment. Households receiving remittances may use them for many purposes: to supplement consumption, to invest in assets such as land or real estate, to purchase productive capital such as tools or agricultural inputs, to pay for children's education, to start a small business, to be saved for consumption smoothing, or to fund any of a number of other end uses. How these remittances are used will ultimately determine the extent of their impact on the economy. Thus, it is necessary to examine the factors that influence how households choose to use their remittances and the role that economic institutions play in that decision making process.

One economic institution of particular interest in its relationship with remittances is the financial sector. This relationship is complex because some financial sector services, such as wire-transfer services, act as complements to remittances. Others services, such as small-business loans, may act as substitutes for remittances. Thus, on one hand, development of the financial sector works with and facilitates the flow of remittances, while on the other hand the same financial sector competes against

(C) 2014 Coon; licensee Springer. This is an Open Access article distributed under the terms of the Creative Commons Attribution License (http://creativecommons.org/licenses/by/2.0), which permits unrestricted use, distribution, and reproduction in any medium, provided the original work is properly credited. 


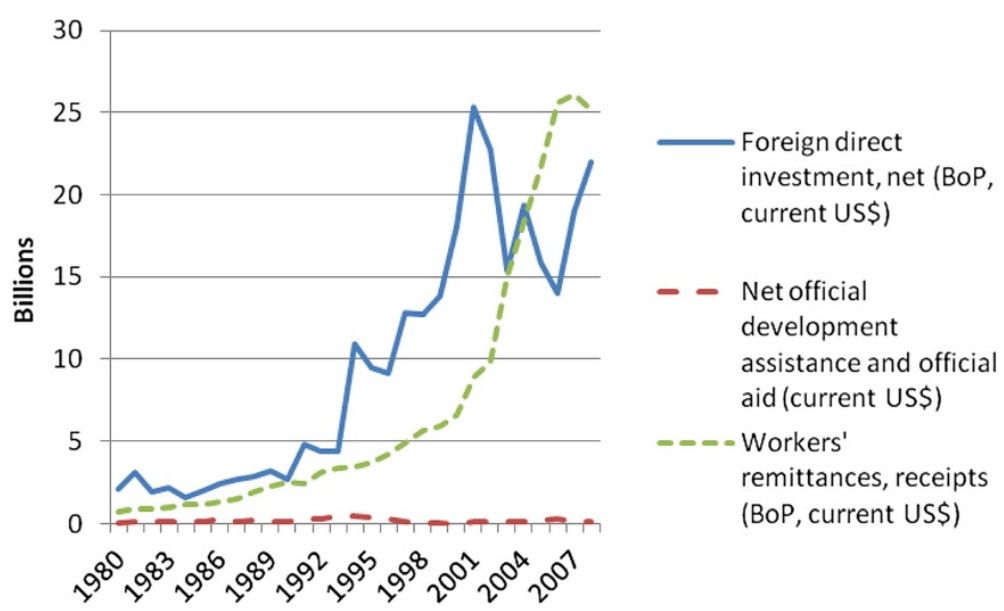

Figure 1 Capital flows to Mexico 1980-2008.

remittances for bank loans. The size of, and degree of competition within, the financial sector will determine whether these opposing interests work, on balance, for or against remittance receiving households. In a best-case scenario, competition will drive down the price of both wire-transfers and loans, thereby increasing the flow of remittances to the community and reducing the cost of borrowing. In a worst-case scenario, banks may attempt to raise the price of wire-transfers in order to make higher interest loans relatively more attractive, thereby reducing the quantities of both. In addition to affecting the flows of remittances and the use of banking services, development of the financial sector will also affect the impact of remittances on the economy by altering the composition of remittance usage in the community. It is the composition of that spending that ultimately determines how remittance flows will affect the economy as a whole.

The current body of research on remittances focuses primarily on the motivations for sending remittances (e.g. to support family members, repay debts, etc.) or on the economic outcomes arising from receiving remittances (e.g. growth, income inequality, education, health, etc.). The majority of the research linking remittances and financial sector development falls into the latter category. Thus, there exists a gap in the research that neglects to examine how households decide for what purpose remittances are used once they are received. The aim of this paper is to begin to fill that gap.

This paper examines the relationship between development of the financial sector and remittance use by testing how the size and scope of the banking system in Mexican communities affects how households choose to spend their remittances. In particular, I test whether there is a difference in remittance use between households in communities where banks are present and communities where they are not. I also test whether the size of the financial sector affects remittance use, as well as whether the types of services offered by banks affect the use of remittances. Section 2 presents a brief review of the literature while Section 3 provides the empirical methodology and data. The main hypotheses are presented in Section 4. Section 5 presents a discussion of the empirical findings and explores potential endogeneity. Section 6 concludes and provides some policy implications. 


\section{Literature review}

\subsection{Microeconomic literature}

One strand in the remittance literature examines how remittances are used in the recipient country. Some studies find remittances to be used for land and capital accumulation. For example, Adams (1998) finds that households in Pakistan use remittance income to increase land holdings. Wouterse and Taylor (2008) find that households in Burkina Faso use remittances to finance purchases of livestock. Yang (2008) finds that remittance-receiving Filipino households are more likely to invest in capital-intensive household businesses. Similarly, Woodruff and Zenteno (2001) find that small businesses in Mexican urban areas receive a significant share of their investment funds from remittances. Several studies have found that households in a number of different countries use remittances to pay for children's educations (e.g. Calero et al. 2009 in Ecuador; Kugler 2006 in Colombia; Edwards and Ureta 2003 in El Salvador; and Yang 2008 in Phillipines). Other studies find remittances to be used overwhelmingly for consumption, healthcare, and housing expenses (Airola 2007; Amuedo-Dorantes 2007; Amuedo-Dorantes et al. 2007; Zarate-Hoyos 2004). The general finding in this literature is that remittances are used for many different purposes, and those purposes depend greatly on the context of the population being studied. However, the microeconomic literature has not been able to explain what drives these different populations to put their remittances to these different uses.

A shortcoming of the literature on remittance use at the household level is that the fungibility of remittance income means that remitted funds are simply added to the larger pool of household income. In order to tease out the uses of remittances, various categories of household expenditures of remittance-receiving households is compared to otherwise similar households that do not receive remittances. The differences in spending are thus attributed to remittances. The problem with this method is that it does not allow researchers to fully account for differences in spending patterns within the population of remittance-receiving households. Since the existing literature finds remittances to be used for a wide variety of purposes depending on the population being studied, and given the fact that the overall impact that remittances will have on the receiving country depends on how remittances are spent, it is important to determine which factors contribute to how remittances are spent by the receiving households. A key advantage of this study is the use of survey data that specifically asks how remittances were spent. Thus, I explore the factors that determine the different uses of remittances between remittance-receiving households.

\subsection{Macroeconomic literature}

There has been some effort in the macroeconomic literature to explain differences between countries using remittances for consumption and countries using remittances for investment by focusing on the impacts of financial sector development. In order to determine whether remittances are primarily used for consumption or investment at the country level researchers compare the flow of remittances with business cycle movements in the receiving country. Chami, et al. (2005) argue that if remittances are to be considered like other forms of capital flows, then it is expected that they would be pro-cyclical in nature as remitters increase the size of their remittances to pursue investment opportunities. However, using a panel of 113 countries they find remittances 
to be counter-cyclical in nature, indicating that remittances are indeed compensatory in nature and, thus, being used primarily to fund consumption. Building on this study, Giuliano and Ruiz-Arranz (2009) introduce controls for financial sector development and find that the counter-cyclical nature of remittances increases as financial development increases. That is, remittances to less financially developed countries are more pro-cyclical. They also find that in less financially developed countries, remittances accelerate growth. This argument is supported by Ramirez and Sharma (2009) who find remittances to be growth enhancing in a panel of 23 LAC countries from 1990-2005. Both of these studies indicate that in areas with low levels of financial development remittances act as substitutes for financial markets. At first glance, this may appear as a disheartening tradeoff, as it seems to indicate that in order to maintain the growth benefits of remittances one should stifle development of the financial sector. Mundaca (2009), however, presents a model in which the financial sector acts as a conduit to channel remittances toward productive investment. Testing her model on a longer panel (1970-2002) of LAC countries, she finds evidence to support her prediction that remittances are growth enhancing at higher levels of financial development. Thus, she finds that remittances and financial development can behave as complements, as well as substitutes.

These country-level studies indicate that the financial sector has a critical role to play in determining how remittances affect the growth and development of the economy. In the absence of financial markets, remittances fill a need for financing productive investments. As the financial sector grows, financial sector services complement remittances and help channel them toward further productive ends. At the same time, however, financial sector services may also supplant remittances and crowd them out toward consumption, minimizing their efficacy as a tool for economic growth and development. A key factor in assessing the strength of the former versus the latter is studying the responses of household behavior regarding the composition of remittance expenditures relative to varying levels of financial development. To date, no such studies exist that analyze the extent to which households use remittances for savings/investment purposes conditional upon the degree of financial development in their community.

Unfortunately, it is not a trivial exercise to find proxies for financial development, particularly ones that may be more appropriate in the context of remittance flows than those used at the country level. The three studies discussed above use a variety of measures of financial development. Mundaca (2009) uses domestic credit provided by the banking sector as a percentage of GDP to proxy for financial development. Ramirez and Sharma (2009) use domestic credit as well as the money supply (M2/GDP) in their empirical models. Giuliano and Ruiz-Arranz (2009) use both of these measures and also include total deposits as a share of GDP and claims on the private sector as a share of GDP. These measures are appropriate for analyzing macroeconomic effects such as GDP growth, but ineffective when examining effects at the household level. This is because financial development is likely to vary within countries as well as between countries. In the case of Mexico, for example, Bouquet (2005, p. 95), citing multiple sources, points out that, "...95\% of Mexico's commercial bank branches are located in communities with over 20,000 residents," and "...fewer than one-third of the country's municipalities...had a financial institution". Thus, changes to the aggregate level of domestic credit may have little impact on remittance-receiving households in rural areas. 
If a sufficiently large share of households lives in these areas, then estimates based on these measures may misrepresent the true relationship between financial development and remittances. Therefore, this paper introduces localized measures of financial development, such as the number of bank branches in a community, and the types of services offered by the banks. These measures provide unique insight into the role of financial development on households' decision-making processes.

The primary contribution of this paper is identifying financial development as a factor that influences the way remittance income is allocated. Prior studies that examine how remittances are used by receiving households primarily compare expenditures of remittance-receiving households to expenditures of non remittancereceiving households. There is little research exploring the variation of remittance usage among remittance receiving households. As one of the only studies doing this, Amuedo-Dorantes (2007) examines the role of immigration documentation status, education, decade of migration, and destination location on whether remittances are used for consumption or asset accumulation for several countries. In the case of Mexico, she finds migrants in the 1990's were more likely to send remittances for the purpose of asset accumulation than migrants in the 2000's, and migrants that settled in large cities were more likely to send remittances for asset accumulation than migrants that settled elsewhere. She also finds that migrants with higher levels of education, and migrants in the 1990's were less likely to send remittances for consumption. These findings are an important step toward understanding how remittances are used, but these findings focus solely on the migrant sending the remittances. This paper adds a new dimension to this analysis by also looking at characteristics of the household receiving the remittances and the characteristics of the community in which the receiving household lives.

\section{Hypotheses}

Households receiving remittances can choose to allocate them toward a variety of activities. Broadly, remittance income can be consumed, invested in productive activity, or saved. Numerous factors determine how remittance income is allocated, including the amount of remittance income, the amount of income from other sources, household size, opportunity cost of investments, access to, and cost of external financing, among others. The aim of this paper is to investigate how these factors influence the household's decision to use remittance income for consumption, saving, and productive investment purposes with particular attention on how these decisions are affected by development of the financial sector.

Development of the financial sector affects remittances in two key ways. First, banks may act as intermediaries in the transmission of remittances. Thus, development of the financial sector should increase competition and drive down the cost of this service. A larger financial sector also provides more access points from which households can retrieve remitted funds, which would potentially lower transaction costs associated with accessing remittance income. When this happens, remittances become a cheaper source of financing for investment and the purchase of household assets. Therefore, it is expected that the use of remittances for these purposes will increase as the financial sector develops. Second, financial services such as small business loans, home mortgages, or consumer lines of credit act as a substitute for many of the roles filled by 
remittances. As the financial sector develops and households begin to utilize the financial sector for their investing needs, it is expected that there will be a decrease in the use of remittances for these purposes.

Thus, there are two opposing effects occurring simultaneously as the financial sector develops. Which effect dominates depends on the relative prices between borrowing and transferring remittances, which in turn may depend on the degree of financial development. Low levels of financial development, in which some banks are available as opposed to no banks, are expected to provide an initial wave of access to external financing where none had previously existed that supersedes the savings from lower transaction costs, implying that more households would borrow. A more developed financial sector generates further price competition for remittance transfers relative to loans because of lower risk and informational costs to the banks. Ultimately this may lead households back toward remittances to finance investments. Also, with competition, banks offer alternative investments such as interest-bearing deposit accounts. Such accounts allow households to save and invest remittances with less risk than before, suggesting that remittances may be diverted away from household production and consumption and put into bank deposits.

The relationship between household remittance income and the financial sector discussed above yields several testable hypotheses. First, households that lack access to financial services are more likely to use remittances to finance productive investments and large purchases, such as homes and land, than those with access. Second, this substitution effect should decline as the financial sector develops. That is, as competition among the financial sector increases, declining transfer costs makes remittances more attractive relative to bank loans. So, at some point, financial sector development can make households more likely to use remittances to finance investments and large purchases. Finally, an increase in the number of financial products should compete with other investment opportunities. Thus, the use of remittances for productive investments will decline as banks begin to offer lower-risk alternative investments.

A key difference between this study and the macroeconomic studies of remittances and financial development is that aggregate measures of financial development and remittances do not account for differences between households and/or between local communities. First, other sources of household income matter. If households are primarily dependent on remittance income, then a majority of this income would be dedicated toward satisfying basic consumption needs. However, households with other sources of income may be able to set aside remittance income for other purposes such as saving or investment. Hence households with more working household members should be less reliant on remittance income for satisfying basic consumption needs. Conditional on the number of workers, however, larger households need to devote more remittance income to consumption. Thus, larger households or households with children would be less likely to use remittances for investment or savings purposes, other things equal. Second, the size of the remittances matter. Since a dollar saved or invested comes at the expense of a dollar's worth of consumption, households receiving larger remittances should be more likely to invest and/or save as the marginal utility of consumption of a remitted dollar declines. By focusing on the household level, I can control for such variables, thus allowing me to examine the influence of the development of the financial sector on households' use of remittance income. 


\section{Methodology and data}

\subsection{Data}

The relationship between remittance use and financial sector development is analyzed using Mexican household survey data over the period 1997-2005. The Mexican household survey data report the size of average monthly remittances received by the household, for what purposes those remittances were spent, as well as other household and community characteristics. The survey data is matched with municipio-level ${ }^{1}$ financial sector data for the time period at which the household began receiving remittances as reported in the survey. The financial sector data report the number of bank branches, and the number of accounts that are held at the banks in the municipios. The household survey communities are sub-units of the municipios, and in some cases more than one community is surveyed within a single municipio.

Data for this investigation come from two primary sources. Data pertaining to the use of remittances by households come from the Mexican Migration Project (MMP124). MMP124 is a household survey conducted by Princeton University's Office of Population Research, and the Departamento de Investigación sobre Movimientos Sociales (Social Movement Research Department) of the University of Guadalajara. Since 1982, MMP124 has conducted surveys in 124 communities in 22 Mexican states, as well as within the US. The present paper utilizes data from 72 Mexican communities surveyed between 1997 and 2008. ${ }^{2}$ This subset of data was selected to match the available data pertaining to the Mexican banking sector. The National Commission of Banking and Securities (CNBV, Mexico) was created in April of 1995 through the merger of the National Commission of Banking and the National Commission of Securities. Shortly thereafter, in September of 1996, CNBV began providing quarterly municipio-level data on the size of banking operations. The banking data for this paper include the years 1997-2007 for which there are four quarterly observations corresponding to years of migration of surveyed households.

The data set consists of 820 remittance-receiving households in the 72 communities. The average monthly remittance (measured in 2005 US\$) received by each household ranges from as little as $\$ 23$ to over $\$ 11000$, with a mean of $\$ 594$ and a median of $\$ 354$. Figure 2 presents a histogram of these average monthly remittances. ${ }^{3}$ After reporting their average monthly remittances, respondents are asked to list their categories of spending. The categories and share of respondents reporting using remittances for each purpose are listed in Table 1. Remittance uses are not mutually exclusive ${ }^{4}$ and MMP124 reports up to five different uses per household. A drawback to the data is that there is no way to distinguish which uses are most important to the household, either by ordinal ranking or shares of total remittances being spent. The most common response by far was for food and maintenance with $93.5 \%$ of the respondents indicating remittances were used for that purpose. The next most common uses are education expenses (35.9\%), construction or repair of a home (26.7\%), health care expenses (24.5\%), paying debts $(13.8 \%)$, and consumer goods (10.2\%). Less than five percent of respondents report using remittances for purposes that may be considered productive investments. These include starting a business (2.4\%), and the purchase of tools (1.1\%), livestock (1.1\%), or agricultural inputs $(0.6 \%)$.

In addition to identifying how financial development affects specific uses for remittances I also want to identify how financial development affects more general uses of 


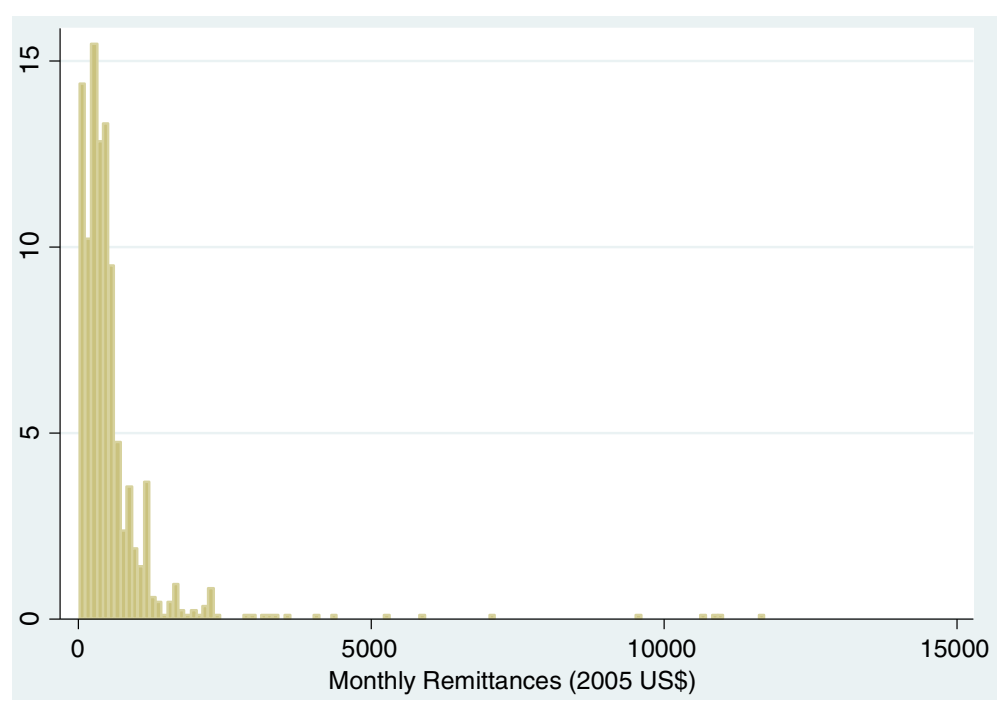

Figure 2 Histogram of migrant remittances.

remittances as described in the macroeconomic literature. That is, I want to identify if development of the financial sector influences households' use of remittances for investment/saving purposes as opposed to consumption. Thus, in this study remittance uses are also aggregated into three broad categories: 1) consumption, which includes consumer goods, special events, entertainment, and other; 2) productive investments, which includes purchase of tools, livestock, and agricultural inputs, and starting or expanding a business; and 3) household assets, which include purchasing a vehicle, a home or lot, or construction or repair of a home. A household is included in any of

Table 1 Remittance uses

\begin{tabular}{ll}
\hline Remittance use & Share of responses (\%) \\
\hline Food and maintenance & 93.54 \\
Construction or repair of home & 26.71 \\
Purchase of home or lot & 2.93 \\
Vehicle & 1.71 \\
Tools & 1.10 \\
Livestock & 1.10 \\
Agricultural inputs & 0.61 \\
Consumer goods & 10.24 \\
Start or expand a business & 2.44 \\
Education & 35.85 \\
Health care & 24.51 \\
Pay debt & 13.78 \\
Special event & 1.46 \\
Entertainment & 0.98 \\
Savings & 8.17 \\
Other & 3.29 \\
\hline
\end{tabular}

Source: Author's Calculation using MMP124. Note: Since households can report multiple uses, shares do not sum to $100 \%$. 
these categories if they report using remittances for at least one of the purposes in the group. Another benefit of aggregating the data into these broader categories is that it allows for greater empirical flexibility. Since the sample size is relatively small, and some of the proportions of households using remittances for individual purposes are as low as one percent, in many cases the probit model becomes inestimable. Thus, aggregation provides greater variation, which allows for inclusion of more control variables in the probit model.

Financial sector data are reported quarterly at the municipio level. For this analysis annualized data are constructed by averaging the four quarters for a given year. Population-adjusted, sample-weighted statistics are reported in Table 2. The $72 \mathrm{com}$ munities in the data set lie within 57 municipios, and financial sector development varies widely among them. Financial sector development is measured across three dimensions: whether there are banks present, the number of bank branches in a municipio, and whether banks offer demand deposit saving accounts and credit cards. After adjusting for population size and pairing the banking data with the survey data, I find that forty-three percent of the households sampled live in municipios with no banks. For those living in municipios where banks are present, eighty-five percent live in municipios where demand-deposit saving accounts are offered; seventy-nine percent live in municipios where credit cards are offered; and the average number of bank branches is less than one for every 10,000 residents. Usage of the banks also varies widely. For example, the number of checking accounts open in a municipio with banks present ranges from 63 per 10,000 residents to 6,213 per 10,000 residents. That is, in one community less than one percent of the population uses a checking account, whereas in another as much as 62 percent of the population uses them.

\subsection{Empirical methodology}

The aim of this empirical analysis is to identify the effects of financial sector development on households' choices over how to use remittance income. Given the complex nature of the relationship between the financial sector and remittance use, it is necessary to conduct the analysis in several stages. The most fundamental form of financial development is whether a banking sector exists at all. Thus, I first investigate whether

Table 2 Population-adjusted, sample-weighted banking statistics

\begin{tabular}{|c|c|c|c|c|c|c|}
\hline & & \multicolumn{5}{|c|}{ Financial variables per 10,000 residents } \\
\hline & & Branches & $\begin{array}{l}\text { Checking } \\
\text { accounts }\end{array}$ & $\begin{array}{l}\text { Credit card } \\
\text { accounts }\end{array}$ & $\begin{array}{l}\text { Savings } \\
\text { accounts }\end{array}$ & $\begin{array}{l}\text { Time deposit } \\
\text { accounts }\end{array}$ \\
\hline \multirow[t]{2}{*}{ Full sample } & Min & 0 & 0 & 0 & 0 & 0 \\
\hline & Max & 3.9 & 6212.95 & 2522.7 & 2393.84 & 3641.88 \\
\hline \multirow[t]{3}{*}{$N=820$} & Median & .38 & 208.7 & 0 & 0 & 224.91 \\
\hline & Mean & .53 & 513.96 & 71.36 & 185.29 & 531.53 \\
\hline & Standard deviation & .70 & 835.03 & 228.31 & 330.76 & 756.43 \\
\hline \multirow[t]{4}{*}{ Branch >0 } & Min & .13 & 63.35 & 0 & 0 & 19.41 \\
\hline & $\operatorname{Max}$ & 3.9 & 6212.95 & 2522.7 & 2393.84 & 3641.88 \\
\hline & Median & .76 & 612.68 & 33.77 & 195.85 & 643.92 \\
\hline & Mean & .94 & 908.29 & 124.89 & 327.46 & 939.44 \\
\hline$N=464$ & Standard deviation & .70 & 935.13 & 292.23 & 383.24 & 792.57 \\
\hline
\end{tabular}


there is a significant difference in remittance use between households in communities where a banking system exists and those in unbanked communities, excluding any other influencing factors. This is done by conducting a z-test for the difference in proportions of households reporting using remittances for various purposes. I test for differences in each specific usage categories that households report, as well as three broad categories of consumption, household assets, and productive investment. Second, I conduct a probit analysis on the three broad categories across three different measures of financial development. The probit model is specified as

$$
y_{i}=\alpha+\beta f_{j}+\Gamma Z+\varepsilon
$$

where $y_{i}$ is a binary variable equal to 1 if remittances are used for purpose $i, f_{j}$ is a measure of financial development, and $\mathrm{Z}$ is a vector of controls. Each of the three measures of $f_{j}$ tests different aspects of financial sector development while controlling for other household and community characteristics. As with the z-test above, the first measure, a dummy variable indicating the presence of at least one bank in the municipio, tests the relationship between remittance use and the existence of a banking system within a community while controlling for other possible factors influencing remittance use. The second measure tests the relationship between remittance use and the size of the banking sector, measured as number of bank branches per 10,000 residents, conditional upon the fact that at least one bank is present in the community. The third measure tests the relationship between remittance use and financial products offered using dummy variables for whether or not banks offer demand deposit saving accounts and credit card accounts.

\section{Results}

\subsection{Existence of the financial sector}

\subsubsection{Difference in population proportions test}

In the first stage of the analysis I test whether remittance use differs between households in communities where a financial sector exists and where it does not, measured by the existence of a banking sector. Specifically, I examine whether remittances are being used as a substitute for financial sector services. The data are classified into two groups: banked and unbanked. A household is classified as unbanked if they live in a community that has no banks operating within its municipio, and a household is classified as banked if they reside in a community that has at least one bank operating in its municipio. Note that this classification does not distinguish whether or not household members have bank accounts, since this information is not recorded in the survey; the financial sector data only shows whether or not banks are present in their community. A difference in population proportion test is conducted for each of the possible reported uses of remittances to determine if households in unbanked communities are more or less likely to use remittances for these purposes than their counterparts in banked communities.

Table 3 shows that households in unbanked communities report significantly higher usage of remittances for purchasing household assets and productive inputs, relative to their counterparts in banked areas. Indeed, households in unbanked communities use remittances for productive purposes at twice the rate of households in banked communities. Examination of the individual uses of remittances in the top half of the table finds that households in unbanked areas report using remittances for construction and 
Table 3 Difference in proportions test: unbanked versus banked communities

\begin{tabular}{|c|c|c|c|c|}
\hline \multirow[t]{2}{*}{ Remittance use } & \multicolumn{4}{|c|}{ Sample proportions } \\
\hline & $\begin{array}{l}\text { Unbanked } \\
(\mathrm{N}=356)\end{array}$ & $\begin{array}{l}\text { Banked } \\
(\mathrm{N}=464)\end{array}$ & Difference & $\mathbf{Z}$ \\
\hline Food and maintenance & 0.9213 & 0.9461 & -0.0247 & -1.43 \\
\hline Construction or repair of home & 0.3174 & 0.2284 & $0.0890^{* * *}$ & 2.85 \\
\hline Purchase of home or lot & 0.0365 & 0.0237 & .0128 & 1.08 \\
\hline Vehicle & 0.0169 & 0.0172 & -0.0003 & -0.04 \\
\hline Tools & 0.0169 & 0.0065 & $0.0104^{*}$ & 1.42 \\
\hline Livestock & 0.0169 & 0.0065 & $0.0104^{*}$ & 1.42 \\
\hline Agricultural inputs & 0.0149 & 0 & $0.0149^{* * *}$ & 2.56 \\
\hline Consumer goods & 0.1461 & 0.0690 & $0.0771^{* * *}$ & 3.61 \\
\hline Start or expand a business & 0.0281 & 0.0216 & 0.0065 & 0.60 \\
\hline Education & 0.3820 & 0.3405 & 0.0415 & 1.23 \\
\hline Health care & 0.2612 & 0.2328 & 0.0285 & 0.94 \\
\hline Pay debt & 0.1713 & 0.1121 & $0.0592^{* * *}$ & 2.44 \\
\hline Special event & 0.0197 & 0.0108 & 0.0089 & 1.05 \\
\hline Entertainment & 0.0084 & 0.0108 & -0.0024 & -0.34 \\
\hline Savings & 0.1236 & 0.0496 & $0.0740^{* * *}$ & 3.84 \\
\hline Other & 0.0365 & 0.0302 & 0.0063 & 0.50 \\
\hline $\begin{array}{l}\text { Assets (includes construction or repair of home, purchase } \\
\text { of home or lot, and vehicle) }\end{array}$ & 0.3455 & 0.2651 & $0.0804^{* * *}$ & 2.49 \\
\hline $\begin{array}{l}\text { Production (includes tools, livestock, agricultural inputs, } \\
\text { and start or expand business) }\end{array}$ & 0.0702 & 0.0323 & $0.0379^{* * *}$ & 2.50 \\
\hline $\begin{array}{l}\text { Consumption (includes consumer goods, special event, } \\
\text { and entertainment) }\end{array}$ & 0.2079 & 0.1142 & $0.0936^{* * *}$ & 3.67 \\
\hline
\end{tabular}

repair of homes, purchasing tools, livestock, agricultural inputs, and consumer goods at higher rates than those with banks in their communities. They also report higher shares of households using remittances as savings or to pay down debts. There is, however, no significant difference in spending between the two groups in areas where it could be expected to not see a difference. That is, areas where households would typically not pursue bank finance, such as food and maintenance, entertainment, or financing special events, are financed by remittances equally in banked and unbanked communities. There is no significant difference between the two groups in the share of households that report using remittances for purchasing vehicles, starting or expanding a business, education, or healthcare, although these purposes could reasonably be uses in which remittances and bank financing could be substitutes.

\subsubsection{Probit model}

The estimates presented above provide suggestive evidence of a relationship between remittance use and financial sector development. Such a rudimentary test, however, fails to control for other factors that may contribute to the differences in remittance use between the two groups. First, urban communities are much more likely to have banks than rural areas. Seventy-eight percent of households in urban communities fall 
into the banked category, compared to only forty-four percent of rural households. If urban households face higher prices it would be expected that they are more likely to need to use additional remittance income to cover cost of living expenses, thus making them more likely to use remittances for food and maintenance and less likely to use them for investment purposes. Furthermore, given that such a high share of households use at least some of their remittance income for basic necessities (95\%), those that receive larger monthly remittances would be more likely to use them for other purposes, such as investment. So, it is possible that any differences in remittance size may be driving the difference in usage between the two groups. Likewise, other characteristics of the household and its members influence how remittances are spent. Households with children are likely to spend more on necessities and education, and therefore likely to devote fewer remittances to saving and investment. Lastly, education may play a role in a household's investment choices. Those with low levels of education may lack the skills or knowledge to engage in productive investment. Hence, it is expected that there will be an increase in remittances used for productive investments as education level of the household head rises.

The following set of probit estimates introduces a set of control variables for these other influences. The control variables for the probit estimates are the logarithm of average monthly remittances sent by the migrant; a dummy variable equal to one if the community is in an urban area; a dummy variable equal to one if the household has children living in it; the size of the household; the number of household members who are employed; the age of the household head; and a set of dummy variables for education level of the household head divided into four groups: less than 6 years, 6-8 years, 9-11 years, and 12 or more years. Summary statistics for all control variables are presented in Table 4. Standard errors are clustered at the municipo level.

The first use of the probit model tests whether the existence of a financial sector influences households' use of remittances by estimating the model on the entire sample of remittance-receiving households. The independent variables for this estimation are the set of controls and a dummy variable equal to one if at least one bank was in operation in the municipio during the period in which the household was receiving remittances (Banked). The model is estimated for each of the three aggregate categories of

Table 4 Control variables: summary statistics

\begin{tabular}{|c|c|c|c|c|c|c|}
\hline \multirow[b]{2}{*}{ Variable } & \multicolumn{2}{|c|}{ Full sample $(n=820)$} & \multicolumn{2}{|c|}{ Banked $(n=464)$} & \multicolumn{2}{|c|}{ Unbanked $(n=356)$} \\
\hline & Mean & Std. Dev. & Mean & Std. Dev. & Mean & Std. Dev. \\
\hline Average monthly remittances & 598.52 & 1000.48 & 492.97 & 482.63 & 736.08 & 1404.25 \\
\hline Urban area $=1$ & 0.372 & 0.484 & 0.5129 & 0.5004 & 0.1882 & 0.3914 \\
\hline Children in household = 1 & 0.8915 & 0.3112 & 0.8987 & 0.3020 & 0.8820 & 0.3230 \\
\hline Education $<6$ years & 0.3012 & 0.4591 & 0.3233 & 0.4682 & 0.2725 & 0.4459 \\
\hline Education 6 to 8 years & 0.3634 & 0.4813 & 0.3966 & 0.4897 & 0.3202 & 0.4672 \\
\hline Education 9 to 11 years & 0.2402 & 0.4275 & 0.2004 & 0.4008 & 0.2921 & 0.4554 \\
\hline Education $>11$ years & 0.0951 & 0.2936 & 0.0797 & 0.2712 & 0.1152 & 0.3197 \\
\hline Age of household head & 37.88 & 10.00 & 38.15 & 10.26 & 37.53 & 9.65 \\
\hline Household size & 4.69 & 1.99 & 4.80 & 2.09 & 4.54 & 1.83 \\
\hline Number of employed household members & 1.62 & 1.04 & 1.66 & 1.04 & 1.57 & 1.03 \\
\hline
\end{tabular}


remittance uses described in Section 3. Results are presented in Table 5. The sign of Banked is negative and significant in Columns 1 and 2, indicating that the existence of a financial sector is associated with a reduction in the probability that remittances will be used to purchase household assets or invest in productive activities even after controlling for these other household characteristics. ${ }^{5}$

Furthermore, positive and significant coefficients for the remittance size variable in both of these columns indicate that larger remittances are correlated with a higher probability that remittances are used for these purposes. The results also show that having children is associated with a lower probability of using remittances for purchasing assets, and associated with a higher probability of using remittances to for consumption. Households in which the head has higher levels of education (nine years or more) are also more likely to use remittances to invest in productive activities.

Overall, these results confirm those found in the previous section even after controlling for other influencing factors. The empirical results presented above indicate a significant relationship between the choices households make over the uses of remittances

Table 5 Existence of banking sector

\begin{tabular}{|c|c|c|c|}
\hline & (1) & (2) & (3) \\
\hline & Assets & Production & Consumption \\
\hline \multirow[t]{2}{*}{ Banked } & $-0.276^{*}$ & $-0.421^{* *}$ & -0.230 \\
\hline & $(0.145)$ & $(0.203)$ & $(0.283)$ \\
\hline \multirow[t]{2}{*}{ Log (avg. monthly remittance) } & $0.195^{* * *}$ & $0.268^{* * *}$ & 0.075 \\
\hline & $(0.067)$ & $(0.077)$ & $(0.138)$ \\
\hline \multirow[t]{2}{*}{ Urban area } & -0.137 & -0.015 & 0.297 \\
\hline & $(0.145)$ & $(0.206)$ & $(0.332)$ \\
\hline \multirow[t]{2}{*}{ Children in household } & $-0.650^{* * *}$ & -0.191 & $0.761^{* * *}$ \\
\hline & $(0.242)$ & $(0.273)$ & $(0.250)$ \\
\hline \multirow[t]{2}{*}{ Education 6 to 8 years } & 0.128 & 0.252 & $-0.333^{*}$ \\
\hline & $(0.161)$ & $(0.204)$ & $(0.175)$ \\
\hline \multirow[t]{2}{*}{ Education 9 to 11 years } & -0.017 & $0.482^{* *}$ & $-0.242^{*}$ \\
\hline & $(0.164)$ & $(0.215)$ & $(0.136)$ \\
\hline \multirow[t]{2}{*}{ Education $>11$ years } & 0.294 & $0.514^{*}$ & -0.399 \\
\hline & $(0.315)$ & $(0.304)$ & $(0.403)$ \\
\hline \multirow[t]{2}{*}{ Age of household head } & 0.003 & 0.013 & -0.011 \\
\hline & $(0.008)$ & $(0.012)$ & $(0.010)$ \\
\hline \multirow[t]{2}{*}{ Household size } & 0.001 & $0.088^{* *}$ & -0.047 \\
\hline & $(0.033)$ & $(0.038)$ & $(0.032)$ \\
\hline \multirow[t]{2}{*}{ \# of employed HH members } & -0.087 & -0.090 & $0.208^{* * *}$ \\
\hline & $(0.075)$ & $(0.081)$ & $(0.074)$ \\
\hline \multirow[t]{2}{*}{ Constant } & $-0.970^{*}$ & $-4.067^{* * *}$ & $-1.498^{*}$ \\
\hline & $(0.543)$ & $(0.776)$ & $(0.883)$ \\
\hline N & 820 & 820 & 820 \\
\hline Pseudo $r^{2}$ & 0.055 & 0.093 & 0.052 \\
\hline$p>c h i^{2}$ & 0.000 & 0.000 & 0.001 \\
\hline
\end{tabular}

Standard errors clustered at community level in parentheses.

${ }^{*} p<0.10,{ }^{* *} p<0.05,{ }^{* * *} p<0.01$.

Education coefficients relative to baseline group with less than 6 years education. 
and financial development within their municipios. Results of the difference in proportions tests indicate that households in unbanked areas use remittances for many purposes that one could reasonably expect to fund through bank financing if it were available. In these areas remittances appear to be used as substitutes for mortgages and home equity lines of credit (in the case of purchasing a home or lot, and construction and repair of homes), small business loans (purchase of tools, livestock, agricultural inputs), and credit cards (consumer goods). This evidence supports the idea that households use remittances to overcome liquidity constraints. These results persist when other factors are controlled for using the probit specification.

\subsection{Financial sector development}

\subsubsection{Size of banking sector}

Table 6 provides probit results focusing on the effect of an increase in the size of the financial sector, conditional upon the fact that banks are present. This is done by replacing the dummy variable for whether banks are present used in the first set of probit

Table 6 Size of banking sector

\begin{tabular}{|c|c|c|c|}
\hline & (1) & $(2)$ & (3) \\
\hline & Assets & Production & Consumption \\
\hline \multirow[t]{2}{*}{ Branches per $10 \mathrm{k}$ residents } & -0.026 & $0.532^{* * *}$ & $-0.237^{* *}$ \\
\hline & $(0.122)$ & $(0.201)$ & $(0.116)$ \\
\hline \multirow[t]{2}{*}{ Log (avg. monthly remittance) } & $0.249^{* * *}$ & $0.303^{* * *}$ & 0.072 \\
\hline & $(0.074)$ & $(0.086)$ & $(0.213)$ \\
\hline \multirow[t]{2}{*}{ Urban area } & 0.068 & -0.270 & $0.715^{*}$ \\
\hline & $(0.154)$ & $(0.360)$ & $(0.401)$ \\
\hline \multirow[t]{2}{*}{ Children in household } & $-1.009^{* * *}$ & -0.472 & $1.133^{* * *}$ \\
\hline & $(0.302)$ & $(0.305)$ & $(0.332)$ \\
\hline \multirow[t]{2}{*}{ Education 6 to 8 years } & 0.110 & $1.064^{*}$ & $-0.506^{* * *}$ \\
\hline & $(0.207)$ & $(0.597)$ & $(0.183)$ \\
\hline \multirow[t]{2}{*}{ Education 9 to 11 years } & -0.005 & $1.352^{* *}$ & $-0.447^{* * *}$ \\
\hline & $(0.240)$ & $(0.652)$ & $(0.171)$ \\
\hline \multirow[t]{2}{*}{ Education $>11$ years } & 0.465 & $1.542^{* * *}$ & -0.555 \\
\hline & $(0.449)$ & $(0.539)$ & $(0.573)$ \\
\hline \multirow[t]{2}{*}{ Age of household head } & 0.004 & $0.047^{* *}$ & -0.005 \\
\hline & $(0.011)$ & $(0.019)$ & $(0.015)$ \\
\hline \multirow[t]{2}{*}{ Household size } & 0.040 & 0.046 & $-0.074^{* *}$ \\
\hline & $(0.040)$ & $(0.056)$ & $(0.034)$ \\
\hline \multirow[t]{2}{*}{ \# of employed $\mathrm{HH}$ members } & -0.137 & -0.168 & $0.230^{* * *}$ \\
\hline & $(0.123)$ & $(0.122)$ & $(0.077)$ \\
\hline \multirow[t]{2}{*}{ Constant } & $-1.551^{* *}$ & $-6.664^{* * *}$ & -2.184 \\
\hline & $(0.668)$ & $(1.364)$ & (1.378) \\
\hline$N$ & 464 & 464 & 464 \\
\hline Pseudo $r^{2}$ & 0.066 & 0.224 & 0.119 \\
\hline$p>c h i^{2}$ & 0.000 & 0.001 & 0.000 \\
\hline
\end{tabular}

Standard errors clustered at community level in parentheses.

${ }^{*} p<0.10,{ }^{* *} p<0.05,{ }^{* * *} p<0.01$.

Education coefficients relative to baseline group with less than 6 years education. 
specifications with a continuous variable measuring the number of bank branches per 10,000 residents, and estimating the probit model on the subset of households living in municipios where banks are present. This variable can be thought of as a measure of competition in the financial sector. That is, a higher number of banks per 10,000 residents leads to more competition for customers and should lead to lower prices for both loans and remittance transfer services. Column 2 of Table 6 reports a positive and significant coefficient for the banking variable, which indicates that an increase in the number of bank branches per 10,000 residents is associated with an increase in the probability that a household will use remittances for investment in productive activities, conditional upon the fact that the household lives in a banked community. Although the sign of the coefficient is the opposite of that found in the first probit specification, it is consistent with the hypothesis presented in Section 3. That is, a larger banking system lowers the cost of receiving remittances, either through competitive pricing or ease of access, making remittances a more attractive investment tool. There are also positive and significant effects for all education levels, with the coefficients increasing in magnitude as the education levels rise. Thus, this is suggestive of the fact that there may be greater investment opportunities for those households in which the household head is more educated. Column 3 reports a negative and significant coefficient for the banking variable, which indicates that an increase in the number of bank branches per 10,000 residents is associated with a decrease in the probability that households use remittances for consumption. The coefficient for the banking variable is notably insignificant in column 1 , whereas it was significant in the previous model. This suggests that while remittances may act as substitutes for bank loans to purchase household assets when banks are not present, the growth of the financial sector does not increase or decrease this effect. ${ }^{6}$

Households' choices over the use of remittances vary with the size of the financial sector as well. As the financial sector grows, households gravitate back toward remittances to finance productive investments. This is consistent with the theory that the initial effect of establishment of the financial sector is to satisfy the pent up demand for investment finance, as seen in the existence section. Increasing the number of banks, however, drives down the cost of transfer services faster than the cost of borrowing, making remittances once again the more attractive form of financing. It should be noted that there is no change in the likelihood of using remittances to purchase household assets as the number of banks increases, which suggests that households continue to use bank financing for larger purchases such as homes or land.

Another key result is that there is a reduction of remittance use for general consumption as the financial sector grows. It is interesting to note that the difference in households using remittances for general consumption between banked and unbanked communities had become insignificant after the introduction of control variables. This could indicate that while households in banked areas are less likely to use remittances as a substitute for traditional banking services such as mortgages and business loans, it is not until banks become more prevalent that households begin to use banks for more sophisticated purposes, such as consumption smoothing.

\subsubsection{Financial banking services}

While the presence of banks may be seen as a benchmark of financial development, the types of services banks offer may also be important. There are four types of accounts 
offered by banks in this study: checking accounts, time deposit accounts, demand deposit savings accounts, and credit card accounts. The communities in which banks are present show positive numbers of checking accounts and time deposit accounts. However, not all banked communities offer demand deposit savings accounts or credit card accounts. To test whether the availability of these types of services affect households remittance use decisions, a set of dummy variables is created equal to one if banks in the municipio offer credit card accounts or demand deposit savings accounts.

The probit model is then estimated using the sub-sample of households living in banked communities. Results of this specification are presented in Table 7. Column 2 reports a negative and significant coefficient for the savings account variable, which indicates that the presence of banks offering savings accounts, in addition to checking accounts and time deposits, is associated with a decrease in the probability that households will use remittances for productive investments. Column 3 reports a positive and

Table 7 Banking services

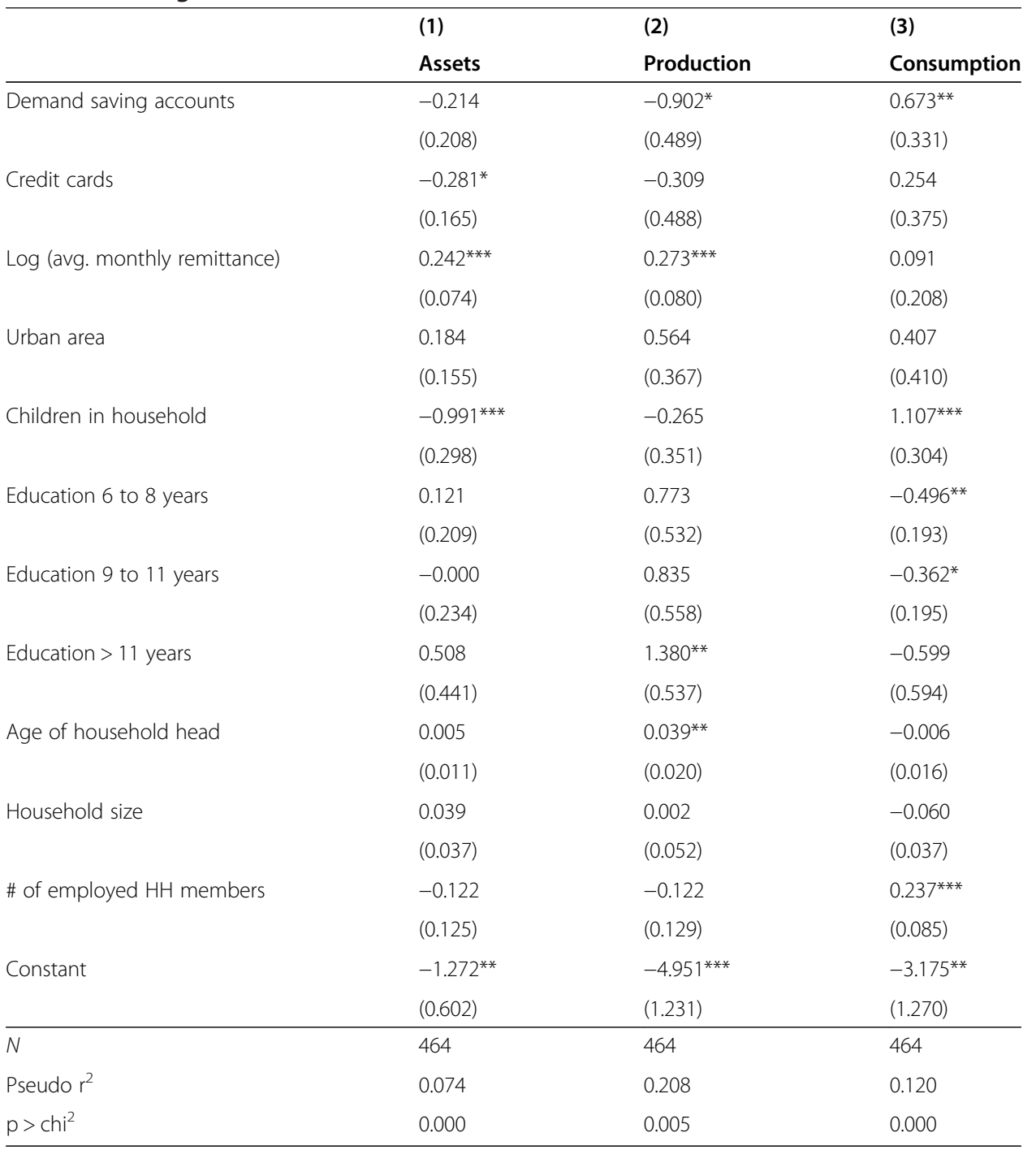

Standard errors clustered at community level in parentheses.

${ }^{*} p<0.10,{ }^{* *} p<0.05,{ }^{* * *} p<0.01$.

Education coefficients relative to baseline group with less than 6 years education. 
significant coefficient for the savings account variable, which indicates that the presence of banks offering savings accounts is associated with an increase in the probability that households use remittances for general consumption. The credit card variable is significant in only one case (column 1) indicating that the presence of banks offering credit card accounts is associated with a decrease in the probability that households use remittances for purchasing household assets. It is of particular interest to note that offering credit cards has no effect on the use of remittances for general consumption or basic necessities. It was expected that the availability of revolving credit would provide the ability of households to use banking services for consumption smoothing, as found in the previous model of financial sector size. A possible explanation is that the availability of financial sector products is less important than consumers' comfort in using them. Thus, households in areas with a larger number of banks may be more familiar with the banking system, and more likely to take advantage of their services than those households where the banking sector is small.

Offering different services affects households' remittance use. In particular, when households have access to safer investment vehicles such as demand deposit savings accounts, they are less likely to use remittances for productive investments. One possible explanation is that these types of accounts offer households a guaranteed return on their investment without having to give up access to these funds. Collectively, these results show that the financial sector has a complex and changing role in a household's decision over how to use remittance income.

\subsection{Potential endogeneity}

One potential concern in the analysis presented in this study is that a bank's decision to open a branch in a particular community is a non-random choice. That is, banks may choose to locate in communities where residents are more likely to use their services, which in turn may be related to migration and remittance patterns. For example, households in communities with a long history of migration may be more likely to use banking services because they have familiarity with the US financial system. Conversely, communities in which migration is a relatively new phenomenon may generally lack financial sector savvy, thus rendering households unlikely to use banking services even if they were readily available. In this case, the use of remittances may influence the pattern of financial development, rather than the other way around. Thus, it is necessary to test for potential endogeneity in the relationship between financial sector development and remittance use, and assess the impact on the results presented in this study.

Demirguc-Kunt et al. (2011) examine the role of remittances on the growth of financial sector breadth and depth. They find that the flow of remittances is positively associated with the growth of the financial sector. Additionally, they develop a set of control variables to control for potential endogeneity between financial development and remittance flows. I utilize their independent variables affecting the growth of the financial sector, as well as their instruments, to test for endogeneity in the present model with respect to the presence of banks in a municipio and the number of branches per 10,000 residents. The geographical distance between the municipio and Mexico City, Mexico's financial center, is used to control for the impact of monitoring costs on a bank's willingness to open in a particular location. The minimum of five times the direct distance to the US border and the distance via the 1920 railroad network plus five times 
the distance from the municipio to the railroad is used to proxy for the historic cost of migration, which in turn proxies for the historic information exchange between return migrants and their home communities with respect to the US financial sector. Additionally, the current share of households receiving remittances also contributes to banks' willingness to locate in a particular community, which was the main finding of Demirguc-Kunt et al. (2011), as does the level of economic activity, measured by per capita GDP in 2000, population density, and distance to the current (1998) rail network. The final controls for the likelihood that households will use banking services are the average education levels of household heads and the share of household heads who speak an indigenous language.

The following presents three IV models used to test for endogeneity. First, a twostage GMM linear probability model is estimated with the dependent banking variable being a dummy equal to one if there is at least one bank present in the municipio. The primary purpose of this model is to establish validity of the instruments being used. Since Demirguc-Kunt et al. (2011) were testing a slightly different model it is necessary to verify that the instruments are valid in this case as well. To be a valid instrument the variables must be correlated with the financial development indication and uncorrelated with the error term of the remittance use equation. The validity of the proposed instruments is tested in the linear probability model using Hansen's test of overidentifying restrictions. Next, a bivariate probit model is estimated to check for endogeneity in the model presented in Table 5. Finally, an IV probit model is estimated to test for endogeneity in the model presented in Table 6. The results of these estimates indicate

Table 8 First-stage regression; dependant variable: banked

\begin{tabular}{lllll}
\hline & Coefficient & Robust standard error & t-statistic & Prob > |t| \\
\hline Log (avg. monthly remittance) & -0.0215 & 0.0167 & -1.2900 & 0.1980 \\
Urban area & 0.1196 & 0.1176 & 1.0200 & 0.3090 \\
Children in household & 0.0310 & 0.0677 & 0.4600 & 0.6480 \\
Education 6 to 8 years & -0.0452 & 0.0317 & -1.4200 & 0.1550 \\
Education 9 to 11 years & -0.1050 & 0.0418 & -2.5100 & 0.0120 \\
Education > 11 years & -0.0574 & 0.0466 & -1.2300 & 0.2190 \\
Age of household head & 0.0013 & 0.0022 & 0.5800 & 0.5640 \\
Household size & 0.0071 & 0.0089 & 0.8000 & 0.4260 \\
\# of employed HH members & -0.0035 & 0.0100 & -0.3500 & 0.7270 \\
GDP 2000 & 0.0002 & 0.0000 & 5.0900 & 0.0000 \\
Pop. density & 0.0000 & 0.0000 & 0.3200 & 0.7480 \\
Indigenous pop. share & 0.1793 & 0.4286 & 0.4200 & 0.6760 \\
Avg. yrs. of schooling of HH heads & -0.0589 & 0.0574 & -1.0300 & 0.3050 \\
Share of HH receiving remittances & 0.0331 & 0.0109 & 3.0300 & 0.0030 \\
Distance to Mexico City & -0.0006 & 0.0002 & -3.5600 & 0.0000 \\
Distance to modern rail system & 0.0017 & 0.0005 & 3.0800 & 0.0020 \\
Distance to 1920 rail & -0.0001 & 0.0001 & -1.1300 & 0.2590 \\
Constant & 0.3066 & 0.2949 & 1.0400 & 0.2990 \\
\hline N & 820 & & & \\
Prob > F & 0.0000 & & & \\
$\mathrm{R}^{2}$ & 0.4567 & & & \\
\hline
\end{tabular}


that the instruments are valid, and there are only signs of endogeneity in one of the six equations, and controlling for this strengthens the results found above.

Table 8 presents the first-stage estimates of the GMM linear probability model. There are four variables which are significant predictors of bank presence. These are GDP, distance from Mexico City, distance to the modern rail network, and the share of households receiving remittances. Table 9 presents the second-stage results of the model along with p-values corresponding to the Sargan test of exogeneity, and Hansen's test of overidentifying restrictions, which tests the validity of instruments. In all equations the $\mathrm{p}$-value for Hansen's J statistic is greater than 0.10 indicating that we cannot reject the null hypothesis that all instruments are valid. On the other hand, the Sargan test for endogeneity suggests that endogeneity is not a statistically significant problem.

Tables 10 and 11 presents the results of the bivariate probit model. Table 10 indicates, as in the GMM model, the significant variables are GDP, distance from Mexico City, distance to the modern rail network, and the share of households receiving

Table 9 2SLS GMM estimates

\begin{tabular}{|c|c|c|c|}
\hline & (1) & (2) & (3) \\
\hline & Assets & Production & Consumption \\
\hline \multirow[t]{2}{*}{ Banked } & $-0.182^{* *}$ & -0.012 & $-0.153^{* *}$ \\
\hline & $(0.085)$ & $(0.027)$ & $(0.077)$ \\
\hline \multirow[t]{2}{*}{ Log (avg. monthly remittance) } & $0.059^{* * *}$ & $0.018^{* * *}$ & $-0.026^{*}$ \\
\hline & $(0.020)$ & $(0.007)$ & $(0.015)$ \\
\hline \multirow[t]{2}{*}{ Urban area } & -0.039 & $-0.025^{*}$ & 0.024 \\
\hline & $(0.051)$ & $(0.015)$ & $(0.050)$ \\
\hline \multirow[t]{2}{*}{ Children in household } & $-0.193^{* *}$ & 0.000 & $0.107^{* *}$ \\
\hline & $(0.079)$ & $(0.023)$ & $(0.048)$ \\
\hline \multirow[t]{2}{*}{ Education 6 to 8 years } & 0.013 & -0.003 & -0.023 \\
\hline & $(0.050)$ & $(0.012)$ & $(0.028)$ \\
\hline \multirow[t]{2}{*}{ Education 9 to 11 years } & -0.027 & 0.001 & -0.041 \\
\hline & $(0.048)$ & $(0.015)$ & $(0.033)$ \\
\hline \multirow[t]{2}{*}{ Education $>11$ years } & -0.010 & 0.014 & 0.011 \\
\hline & $(0.082)$ & $(0.021)$ & $(0.063)$ \\
\hline \multirow[t]{2}{*}{ Age of household head } & -0.000 & -0.000 & -0.000 \\
\hline & $(0.002)$ & $(0.001)$ & $(0.002)$ \\
\hline \multirow[t]{2}{*}{ Household size } & 0.000 & 0.003 & -0.001 \\
\hline & $(0.010)$ & $(0.003)$ & $(0.008)$ \\
\hline \multirow[t]{2}{*}{ \# of employed $\mathrm{HH}$ members } & -0.033 & 0.002 & 0.022 \\
\hline & $(0.021)$ & $(0.005)$ & $(0.014)$ \\
\hline \multirow[t]{2}{*}{ Constant } & $0.303^{*}$ & -0.064 & 0.278 \\
\hline & $(0.162)$ & $(0.058)$ & $(0.187)$ \\
\hline N & 820 & 820 & 820 \\
\hline $\mathrm{p}$ & 0.000 & 0.013 & 0.001 \\
\hline Test of endogeneity (Sargan C Statistic) $p>$ chi $^{2}$ & 0.1836 & 0.2502 & 0.5303 \\
\hline Test of overidentifying Restriction (Hansen J Statistic) $p>c h i^{2}$ & 0.5520 & 0.1804 & 0.5976 \\
\hline
\end{tabular}

Standard errors clustered at community level in parentheses.

${ }^{*} p<0.10,{ }^{* *} p<0.05,{ }^{* * *} p<0.01$.

Education coefficients relative to baseline group with less than 6 years education. 
Table 10 Bivariate probit model; bank presence equation

\begin{tabular}{|c|c|c|c|}
\hline & (1) & $(2)$ & (3) \\
\hline & Assets & Production & Consumption \\
\hline \multirow[t]{2}{*}{ Log (avg. monthly remit.) } & -0.114 & -0.100 & -0.095 \\
\hline & $(0.075)$ & $(0.071)$ & $(0.076)$ \\
\hline \multirow[t]{2}{*}{ Urban area } & 0.332 & 0.318 & 0.325 \\
\hline & $(0.542)$ & $(0.554)$ & $(0.550)$ \\
\hline \multirow[t]{2}{*}{ Children in household } & 0.196 & 0.209 & 0.216 \\
\hline & $(0.225)$ & $(0.211)$ & $(0.217)$ \\
\hline \multirow[t]{2}{*}{ Education 6 to 8 years } & $-0.242^{* *}$ & $-0.237^{*}$ & $-0.251^{*}$ \\
\hline & $(0.122)$ & $(0.129)$ & $(0.147)$ \\
\hline \multirow[t]{2}{*}{ Education 9 to 11 years } & $-0.489^{* * *}$ & $-0.494^{* * *}$ & $-0.501^{* * *}$ \\
\hline & $(0.138)$ & $(0.134)$ & $(0.142)$ \\
\hline \multirow[t]{2}{*}{ Education $>11$ years } & $-0.296^{*}$ & $-0.358^{* *}$ & $-0.368^{* *}$ \\
\hline & $(0.177)$ & $(0.171)$ & $(0.174)$ \\
\hline \multirow[t]{2}{*}{ Age of household head } & 0.002 & 0.002 & 0.001 \\
\hline & $(0.009)$ & $(0.009)$ & $(0.009)$ \\
\hline \multirow[t]{2}{*}{ Household size } & 0.058 & 0.054 & 0.054 \\
\hline & $(0.042)$ & $(0.044)$ & $(0.044)$ \\
\hline \multirow[t]{2}{*}{ \# of employed HH members } & 0.020 & 0.015 & 0.017 \\
\hline & $(0.055)$ & $(0.049)$ & $(0.051)$ \\
\hline \multirow[t]{2}{*}{ GDP 2000} & $0.001^{* * *}$ & $0.001^{* * *}$ & $0.001^{* * *}$ \\
\hline & $(0.000)$ & $(0.000)$ & $(0.000)$ \\
\hline \multirow[t]{2}{*}{ Pop. density } & -0.000 & -0.000 & -0.000 \\
\hline & $(0.000)$ & $(0.000)$ & $(0.000)$ \\
\hline \multirow[t]{2}{*}{ Indigenous pop. share } & 2.758 & 2.798 & 2.812 \\
\hline & $(1.795)$ & $(1.832)$ & $(1.853)$ \\
\hline \multirow[t]{2}{*}{ Avg. yrs. of schooling } & -0.208 & -0.214 & -0.199 \\
\hline & $(0.263)$ & $(0.282)$ & $(0.318)$ \\
\hline \multirow[t]{2}{*}{ Share receiving remittances } & $0.127^{* * *}$ & $0.130^{* * *}$ & $0.131^{* * *}$ \\
\hline & $(0.044)$ & $(0.043)$ & $(0.044)$ \\
\hline \multirow[t]{2}{*}{ Distance to Mexico City } & $-0.003^{* * *}$ & $-0.003^{* * *}$ & $-0.003^{* * *}$ \\
\hline & $(0.001)$ & $(0.001)$ & $(0.001)$ \\
\hline \multirow[t]{2}{*}{ Distance to modern rail system } & $0.006^{* *}$ & $0.006^{* *}$ & $0.005^{*}$ \\
\hline & $(0.003)$ & $(0.003)$ & $(0.003)$ \\
\hline \multirow[t]{2}{*}{ Distance to 1920 rail } & -0.001 & -0.001 & -0.001 \\
\hline & $(0.000)$ & $(0.001)$ & $(0.001)$ \\
\hline \multirow[t]{2}{*}{ Constant } & -0.761 & -0.710 & -0.768 \\
\hline & $(1.560)$ & $(1.634)$ & $(1.655)$ \\
\hline
\end{tabular}

Standard errors clustered at community level in parentheses.

${ }^{*} p<0.10,{ }^{* *} p<0.05,{ }^{* * *} p<0.01$.

Education coefficients relative to baseline group with less than 6 years education.

remittances. Table 11 presents the results of the remittance use equations. In five of the six cases, the null hypothesis that the equations are exogenous cannot be rejected. Only for column 1, using remittances to purchase assets, is there evidence of endogeneity. Furthermore, the banking coefficient in column 1 is of the same sign as the banking 
Table 11 Bivariate probit; remittance use equations

\begin{tabular}{|c|c|c|c|}
\hline & (1) & $(2)$ & (3) \\
\hline Dependant variable & Assets & Production & Consumption \\
\hline \multirow[t]{2}{*}{ Banked } & $-0.699 * * *$ & -0.532 & -0.341 \\
\hline & $(0.252)$ & $(0.465)$ & $(0.771)$ \\
\hline \multirow[t]{2}{*}{ Log (avg. monthly remittance) } & $0.172^{* * *}$ & $0.260^{* * *}$ & 0.070 \\
\hline & $(0.066)$ & $(0.088)$ & $(0.144)$ \\
\hline \multirow[t]{2}{*}{ Urban area } & 0.041 & 0.037 & 0.343 \\
\hline & $(0.174)$ & $(0.312)$ & $(0.420)$ \\
\hline \multirow[t]{2}{*}{ Children in household } & $-0.603^{* *}$ & -0.183 & $0.765^{* * *}$ \\
\hline & $(0.248)$ & $(0.276)$ & $(0.252)$ \\
\hline \multirow[t]{2}{*}{ Education 6 to 8 years } & 0.110 & 0.245 & $-0.336^{*}$ \\
\hline & $(0.163)$ & $(0.202)$ & $(0.174)$ \\
\hline \multirow[t]{2}{*}{ Education 9 to 11 years } & -0.069 & $0.464^{* *}$ & $-0.254^{*}$ \\
\hline & $(0.161)$ & $(0.214)$ & $(0.149)$ \\
\hline \multirow[t]{2}{*}{ Education $>11$ years } & 0.259 & $0.506^{*}$ & -0.405 \\
\hline & $(0.315)$ & $(0.306)$ & $(0.398)$ \\
\hline \multirow[t]{2}{*}{ Age of household head } & 0.002 & 0.013 & -0.011 \\
\hline & $(0.008)$ & $(0.012)$ & $(0.010)$ \\
\hline \multirow[t]{2}{*}{ Household size } & 0.002 & $0.088^{* *}$ & -0.046 \\
\hline & $(0.034)$ & $(0.038)$ & $(0.033)$ \\
\hline \multirow[t]{2}{*}{ \# of employed HH members } & -0.078 & -0.088 & $0.209^{* * *}$ \\
\hline & $(0.073)$ & $(0.081)$ & $(0.073)$ \\
\hline \multirow[t]{2}{*}{ Constant } & -0.641 & $-3.963^{* * *}$ & -1.421 \\
\hline & $(0.507)$ & $(0.860)$ & $(1.044)$ \\
\hline Wald test of exogeneity & $0.358^{* *}$ & 0.089 & 0.097 \\
\hline Rho & $(0.138)$ & 0.288 & 0.466 \\
\hline N & 820 & 820 & 820 \\
\hline Prob $>F$ & 0.000 & 0.000 & 0.004 \\
\hline
\end{tabular}

Standard errors clustered at community level in parentheses.

${ }^{*} p<0.10,{ }^{* *} p<0.05,{ }^{* * *} p<0.01$.

Education coefficients relative to baseline group with less than 6 years education.

coefficient of column 1 of Table 5 . However, the coefficient in Table 11 is now more significant and of larger magnitude. Thus, controlling for endogeneity strengthens the results found in Table 5 .

Tables 12 and 13 present the results of the IV probit model, which tests the impact of the size of the banking sector, measured as number of branches per 10,000 residents, on remittance use for all municipios in which at least one bank is present. As seen in Table 12 the significant instruments are distance from Mexico City, distance to the modern rail network, the share of households receiving remittances, population density, the share of households speaking an indigenous language, and in all but two cases GDP. Table 13 indicates that the null hypothesis of exogeneity cannot be rejected for all remittance uses.

The overall finding of the instrumental variables models is that endogeneity is not present in the majority of the models presented above. In the one case where endogeneity is present, the results of the IV model only serves to support the overall conclusion. 
Table 12 IV probit first-stage estimates; dependant variable: branches per $10 \mathrm{k}$ residents

\begin{tabular}{|c|c|c|c|}
\hline & $(1)$ & $(2)$ & (3) \\
\hline & Assets & Production & Consumption \\
\hline \multirow[t]{2}{*}{ Log (avg. monthly remit.) } & -0.026 & -0.025 & -0.032 \\
\hline & $(0.017)$ & $(0.017)$ & $(0.024)$ \\
\hline \multirow[t]{2}{*}{ Urban area } & $0.381^{* *}$ & $0.381^{* *}$ & $0.348^{* *}$ \\
\hline & $(0.151)$ & $(0.155)$ & $(0.153)$ \\
\hline \multirow[t]{2}{*}{ Children in household } & -0.076 & -0.085 & -0.046 \\
\hline & $(0.083)$ & $(0.084)$ & $(0.096)$ \\
\hline \multirow[t]{2}{*}{ Education 6 to 8 years } & -0.031 & -0.030 & -0.041 \\
\hline & $(0.043)$ & $(0.043)$ & $(0.041)$ \\
\hline \multirow[t]{2}{*}{ Education 9 to 11 years } & $-0.249^{* *}$ & $-0.243^{* *}$ & $-0.280^{* *}$ \\
\hline & $(0.114)$ & $(0.113)$ & $(0.142)$ \\
\hline \multirow[t]{2}{*}{ Education $>11$ years } & -0.135 & -0.120 & -0.166 \\
\hline & $(0.108)$ & $(0.101)$ & $(0.142)$ \\
\hline \multirow[t]{2}{*}{ Age of household head } & $-0.008^{* *}$ & $-0.008^{* *}$ & $-0.008^{* *}$ \\
\hline & $(0.004)$ & $(0.004)$ & $(0.004)$ \\
\hline \multirow[t]{2}{*}{ Household size } & $-0.042^{* *}$ & $-0.041^{* *}$ & $-0.047^{* *}$ \\
\hline & $(0.020)$ & $(0.020)$ & $(0.020)$ \\
\hline \multirow[t]{2}{*}{ \# of employed HH members } & -0.042 & -0.046 & -0.035 \\
\hline & $(0.039)$ & $(0.041)$ & $(0.035)$ \\
\hline \multirow[t]{2}{*}{ GDP 2000} & 0.000 & $0.000^{* *}$ & 0.000 \\
\hline & $(0.000)$ & $(0.000)$ & $(0.000)$ \\
\hline \multirow[t]{2}{*}{ Pop. density } & $0.000^{* * *}$ & $0.000^{* * *}$ & $0.000^{* *}$ \\
\hline & $(0.000)$ & $(0.000)$ & $(0.000)$ \\
\hline \multirow[t]{2}{*}{ Indigenous pop. share } & $-1.184^{*}$ & $-1.225^{*}$ & $-1.146^{*}$ \\
\hline & $(0.655)$ & $(0.629)$ & $(0.696)$ \\
\hline \multirow[t]{2}{*}{ Avg. yrs. of schooling } & 0.088 & 0.084 & 0.152 \\
\hline & $(0.126)$ & $(0.125)$ & $(0.156)$ \\
\hline \multirow[t]{2}{*}{ Share receiving remittances } & $0.074^{* * *}$ & $0.075^{* * *}$ & $0.079^{* * *}$ \\
\hline & $(0.023)$ & $(0.023)$ & $(0.022)$ \\
\hline \multirow[t]{2}{*}{ Distance to Mexico City } & $-0.001^{*}$ & $-0.001^{* *}$ & $-0.001^{* *}$ \\
\hline & $(0.000)$ & $(0.000)$ & $(0.000)$ \\
\hline \multirow[t]{2}{*}{ Distance to modern rail system } & $0.002^{* * *}$ & $0.002^{* * *}$ & $0.002^{* * *}$ \\
\hline & $(0.001)$ & $(0.001)$ & $(0.001)$ \\
\hline \multirow[t]{2}{*}{ Distance to 1920 rail } & -0.000 & -0.000 & -0.000 \\
\hline & $(0.000)$ & $(0.000)$ & $(0.000)$ \\
\hline \multirow[t]{2}{*}{ Constant } & 0.176 & 0.142 & 0.132 \\
\hline & $(0.892)$ & $(0.904)$ & $(0.823)$ \\
\hline
\end{tabular}

Standard errors clustered at community level in parentheses.

${ }^{*} p<0.10,{ }^{* *} p<0.05,{ }^{* * *} p<0.01$.

Education coefficients relative to baseline group with less than 6 years education.

\section{Conclusion}

While a growing body of research examines the role of remittances in economic growth and development, how remittance receiving households use remittances may largely determine their role in growth and development. The debate in the macroeconomic 
Table 13 IV probit second-stage estimates

\begin{tabular}{|c|c|c|c|}
\hline & (1) & $(2)$ & (3) \\
\hline Dependant variable & Assets & Production & Consumption \\
\hline \multirow[t]{2}{*}{ Branches per $10 \mathrm{k}$ residents } & 0.152 & $0.611^{*}$ & -0.888 \\
\hline & $(0.359)$ & $(0.345)$ & $(0.659)$ \\
\hline \multirow[t]{2}{*}{ Log (avg. monthly remittance) } & $0.251^{* * *}$ & $0.305^{* * *}$ & 0.054 \\
\hline & $(0.076)$ & $(0.087)$ & $(0.160)$ \\
\hline \multirow[t]{2}{*}{ Urban area } & -0.030 & -0.320 & $0.966^{* *}$ \\
\hline & $(0.249)$ & $(0.470)$ & $(0.378)$ \\
\hline \multirow[t]{2}{*}{ Children in household } & $-0.994^{* * *}$ & -0.472 & $0.986^{*}$ \\
\hline & $(0.297)$ & $(0.302)$ & $(0.538)$ \\
\hline \multirow[t]{2}{*}{ Education 6 to 8 years } & 0.114 & $1.052^{*}$ & $-0.448^{* * *}$ \\
\hline & $(0.200)$ & $(0.592)$ & $(0.133)$ \\
\hline \multirow[t]{2}{*}{ Education 9 to 11 years } & 0.053 & $1.355^{* *}$ & $-0.602^{* * *}$ \\
\hline & $(0.250)$ & $(0.634)$ & $(0.201)$ \\
\hline \multirow[t]{2}{*}{ Education > 11 years } & 0.474 & $1.520^{* * *}$ & -0.527 \\
\hline & $(0.442)$ & $(0.522)$ & $(0.420)$ \\
\hline \multirow[t]{2}{*}{ Age of household head } & 0.006 & $0.047^{* *}$ & -0.008 \\
\hline & $(0.011)$ & $(0.019)$ & $(0.017)$ \\
\hline \multirow[t]{2}{*}{ Household size } & 0.046 & 0.047 & $-0.091^{* * *}$ \\
\hline & $(0.040)$ & $(0.056)$ & $(0.032)$ \\
\hline \multirow[t]{2}{*}{ \# of employed HH members } & -0.129 & -0.162 & $0.171^{*}$ \\
\hline & $(0.141)$ & $(0.121)$ & $(0.104)$ \\
\hline \multirow[t]{2}{*}{ Constant } & $-1.788^{* *}$ & $-6.720^{* * *}$ & -1.036 \\
\hline & $(0.829)$ & $(1.324)$ & $(2.079)$ \\
\hline \multicolumn{4}{|l|}{ Wald test of exogeneity } \\
\hline \multirow[t]{2}{*}{ Rho } & -0.150 & -0.068 & 0.520 \\
\hline & $(0.253)$ & $(0.221)$ & $(0.562)$ \\
\hline N & 464 & 464 & 464 \\
\hline Prob $>$ F & 0.000 & 0.000 & 0.004 \\
\hline
\end{tabular}

Standard errors clustered at community level in parentheses.

${ }^{*} p<0.10,{ }^{* *} p<0.05,{ }^{* * *} p<0.01$.

Education coefficients relative to baseline group with less than 6 years education

literature centers on whether remittances are primarily used for consumption or for savings and investment. Empirical studies at the macroeconomic level have yielded mixed conclusions. Some studies (e.g., Chami et al. 2005) find remittances to be counter-cyclical, indicating that remittances may be used primarily for consumption. Other studies (e.g., Guiliano and Ruiz-Arranz 2009) find remittances to be pro-cyclical in countries with low levels of financial development, indicating remittances are substitutes for financial sector services, while other studies (e.g., Mundaca 2009) find remittances and financial sector services to be complements. Microeconomic research (e.g., Zarate-Hoyos 2004; Yang 2008; Amuedo-Dorantes and Pozo 2006) has used an outcomes-based approach to examine remittance use, but has not adequately examined the factors that influence these uses. This paper bridges the gap between the two strands of the literature by examining how financial sector development affects the use of remittances at the household level. I find that in the absence of a banking system, 
remittances act as a substitute for bank loans by being used to finance asset accumulation and productive investment. Policies directed toward providing access to financial services may help reduce the need for households to go abroad to overcome liquidity constraints. Furthermore, I also find that the relationship between financial development and remittance use evolves as the financial sector develops. As financial sector services become more widely available, the role of remittances shifts from one purpose to another. Thus, further policies aimed to grow the financial sector can also exploit complementarities between remittances and financial sector services, thereby maximizing the potential gains from remittance inflows.

\section{Endnotes}

${ }^{1}$ The literal translation of municipio is municipality. In Mexico, they are roughly the administrative equivalent of a county in the US.

${ }^{2}$ The remaining 52 communities were excluded because they were surveyed prior to 1997 , which is the first year for which the financial sector data are available.

${ }^{3}$ Ninety-five percent of the remittances are below $\$ 1500$ per month and ninety-nine percent are below $\$ 4500$ per month. The empirical results are robust to the exclusion of extreme values.

${ }^{4}$ This is why multinomial probit/logit are not used in this paper.

${ }^{5}$ Potential endogeneity of the financial sector variables is addressed using an Instrumental Variables (IV) model in Section 5.3.

${ }^{6}$ As a robustness check, the size of the banking sector was also measured using dummy variables indicating low, intermediate, and high concentrations of banks based on the distribution of bank branches per capita. The results are consistent with those found here, and are available from the author upon request.

\section{Abbreviations}

MMP124: Mexican Migration Project 124 community survey; CNBV: Comision Nacional Bancarios y de Valores (National Commission of Banking and Securities).

\section{Competing interests}

The IZA Journal of Labor \& Development is committed to the IZA Guiding Principles of Research Integrity. The author declares that he has observed these principles.

\section{Acknowledgements}

The author would like to thank Rebecca Neumann, Keith Bender, Scott Adams, an anonymous referee, and discussants at the Eastern Economic Association Conference for helpful comments. A version of this paper appears as a chapter of my PhD dissertation at University of Wisconsin-Milwaukee.

Responsible editor: Jackline Wahba

Received: 20 January 2014 Accepted: 24 March 2014

Published: 13 May 2014

\section{References}

Adams RH Jr (1998) Remittances, investment, and rural asset accumulation in Pakistan. Econ Dev Cult Chang 47(1):155-173 Airola J (2007) The Use of remittance income in Mexico. Int Migr Rev 41(4):850-859

Amuedo-Dorantes C (2007) Remittance patterns of Latin American immigrants in the united states: Kalamazoo. W. E. Upjohn Institute for Employment Research, Mich

Amuedo-Dorantes C, Pozo S (2006) Remittance receipt and business ownership in the Dominican republic. World Econ 29(7):939-956

Amuedo-Dorantes C, Sainz T, Pozo S (2007) Remittances and healthcare expenditure patterns of populations in origin communities: evidence from Mexico. Integration Trade 11(27):159-184

Bouquet E (2005) Remittances and Financial Services. In: Merz BJ (ed) New Patterns for Mexico: Observations on Remittances, Philanthropic Giving, and Equitable Development/Nuevas Pautas para Mexico: Observaciones sobre Remesas, Donaciones Filantropicas y Desarrollo Equitativo. Studies in Global Equity, Harvard University Press, Cambridge and London, pp 50-70

Calero C, Bedi AS, Sparrow R (2009) Remittances, liquidity constraints and human capital investments in Ecuador. World Dev 37(6):1143-1154 
Chami R, Fullenkamp C, Jahjah S (2005) Are immigrant remittance flows a source of capital for development? IMF Staff Pap 52(1):55-81

Demirguc-Kunt A, Cordova EL, Martinez Peria MS, Woodruff C (2011) Remittances and banking sector breadth and depth. J Dev Econ 95(2):229-41

Edwards AC, Ureta M (2003) International migration, remittances, and schooling: evidence from El Salvador. J Dev Econ 72(2):429-461

Giuliano P, Ruiz-Arranz M (2009) Remittances, financial development, and growth. J Dev Econ 90(1):144-152

Kugler M (2006) Migrant remittances, human capital formation and job creation externalities in Colombia. Coyuntura Social 34:45-71

Mundaca BG (2009) Remittances, financial market development, and economic growth: the case of Latin America and the Caribbean. Rev Dev Econ 13(2):288-303

Ramirez MD, Sharma H (2009) Remittances and growth in Latin America: a panel unit root and panel cointegration analysis. Estudios Economicos de Desarrollo Internacional 9(1):5-32

Woodruff CM, Zenteno R (2001) Remittances and microenterprises in Mexico. UCSD; Graduate School of International Relations and Pacific Studies Working Paper. Available at SSRN: http://ssrn.com/abstract=282019 or http://dx.doi. org/10.2139/ssrn.282019

World Bank (2010) World dataBank., http://databank.worldbank.org. Retreived November 2010

Wouterse F, Taylor JE (2008) Migration and income diversification: evidence from Burkina Faso. World Dev 36(4):625-640

Yang D (2008) International migration, remittances and household investment: evidence from Philippine migrants' exchange rate shocks. Econ J 118(528):591-630

Zarate-Hoyos GA (2004) Consumption and remittances in migrant households: toward a productive use of remittances. Contemp Econ Policy 4:555-565

10.1186/2193-9020-3-7

Cite this article as: Coon: Financial development and the end-use of migrants' remittances. IZA Journal of Labor \& Development 2014, 3:7

\section{Submit your manuscript to a SpringerOpen ${ }^{\circ}$ journal and benefit from:}

- Convenient online submission

- Rigorous peer review

- Immediate publication on acceptance

- Open access: articles freely available online

- High visibility within the field

Retaining the copyright to your article

Submit your next manuscript at $\gg$ springeropen.com 